\title{
A BRIEF REVIEW ON PHYTOCHEMICAL AND BIOLOGICAL ACTIVITIES OF CORCHORUS DEPRESSUS (LINN.)
}

\author{
Milind Kashinath Patel*1, Swapnil Ghanshyam Dhake ${ }^{2}$, Tejendra Amrut Rajput ${ }^{3}$ \\ ${ }^{1}$ P.S.G.V.P.M's S. I. Patil Arts, G. B. Patel Science and S. T. K. V. S. Commerce College, Shahada, Nandurbar, Maharashtra, India \\ ${ }^{2}$ Department of Engineering Sciences and Humanities, Sandip Foundation's Sandip Institute of Technology \& Research Centre, \\ Mahiravani, Trimbak Road, Nashik, Maharashtra, India \\ ${ }^{3}$ Department of Chemistry, Arts, Commerce and Science College, Onde, Tal-Vikramgad, Dist-Palghar, Maharashtra, India \\ *Corresponding author:mkp23364@gmail.com
}

\begin{abstract}
In the current study, we are emphasizing our investigation on one of the commonly available plant in India i.e., Corchorus depressus (Linn) which belongs to Tiliaceae family. It plays an important role in the treatment of various diseases. Our study is focused on the biologically active ingredients and therapeutic activities of Corchorus depressus (Linn) extract. It aims to highlight the latest research on the different extracts of this plant. Many significant natural products like glycosides, flavonoids, steroids, terpenoids, etc. were isolated by different researchers. These natural products were prone for various therapeutic activities, such as antioxidant, anticancer, antidiabetic, anti-inflammatory, analgesics, wound healing and hepato protective actions, analgesic, diuretic, antifungal, antibacterial, antimalarial, cardiotonic activity, antipyretic and enzyme inhibition. All the information was gathered from global databases such as Elsevier, PubMed, Researchgate, and Web of Science. By considering the pharmacological profile of Corchorus depressus (Linn), this plant might be utilized in various herbal formulations which can be reported in the future. The purpose of the present review is to provide an overview of the extremely diverse phytochemicals present in Corchorus depressus.
\end{abstract}

Keywords: Corchorus depressus (Linn), Tiliaceae, Phytochemical constituents, Secondary metabolites, Pharmacological activity.

\section{INTRODUCTION}

Herbal products are a key source of health care and traditional medical practices for over 4 billion people living in poor nations. Therefore, the use of herbs is considered an important part of the culture of these communities. Traditional herbs are substances derived from plants that have undergone minimal industrial processing and have been used to treat diseases. As a result, traditional herbal medicines have received great attention in the global health debate [1].

Traditional medicine is seen by the World Health Organization (WHO) as a field of medical support, with a complete explanation of knowledge, skills, and exercise, taking into account the assumptions, beliefs, and experiences of other cultures, whether logical or not, and prevention, identification, improvement, or treatment of physical and mental instability [2]. India is famous for its Ayurveda, Siddha and Unani traditional medicine system. The concept of Ayurveda was developed in India between 2500 and 500BC [3]. The use of natural resources in routine life has become a daily Ayurvedic practice for Indians. The basic rule of Ayurvedic treatment consists of two parts. It is about perpetuating the cause of the disease and making the patient more aware of the cause of the disease [4-5].

Medicinal plants are used in traditional drugs aimed at treating various health conditions. The problem of promotion in the use of alternate medications in the developed countries has very little evidence of documentation. It is therefore necessary to document all research work related to traditional medicine and to ensure standardization of the parts of the plant that will be used. So we have planned to carry out the review of Corchorus depressus (Linn). This type of work and research will help in authentication and ensure the reproducibility of herbal merchandise in marketing. Corchorus is a genus of Tiliaceae family. There are 450 species and 50 genera in this family, distributed in 
tropical and subtropical regions of southern Asia and South America. Out of these, nearly 100 species are found to have appreciable therapeutic importance. The species which contribute prominently toward the medicinal properties are:

1. Corchorus depressus 2. Corchorus capsularis 3.Corchorus olitorius 4.Corchorus fascicularis 5. Corchorus pseudocapsularis 6.Corchorus aestuans 7.Corchorus humilis 8.Corchorus siliquosus 9.Corchorus tridens 10.Corchorus trilocularis 11. Corchorus acutangulus 12. Corchorus urticifolius.

The species Corchorus depressus (L.) is attributed to several herbal and indigenous medicinal properties. According to the literature assessment, many phytochemicals isolated from various portions of the plants contribute to a variety of therapeutic qualities. As a result, the current review contains information on the chemical composition and biological properties of various plant parts.

\subsection{Macroscopic characters of Corchorus depressus ( $L$ )}

Corchorus depressus (L.) commonly known as 'Bhedani' (Sanskrit), 'Bauphali' (Hindi) and 'Malukh' (Arabic) is found in drier parts of India such as Odisha, Punjab, Gujarat, and Rajasthan. It grows up to $1000 \mathrm{~m}$ above sea level in arid and semi-arid regions of South Asia and South America. It is about 6-9 inches long and is a ground-creeping woody perennial. Branches radiating from the wooden canopy adhere to the ground. Leaves are 6-20 mm, round, generally wrinkled, glabrous and irregularly circular toothed. The toothing has no appendages; the base is round or wedge-shaped and petiole $1.2-2.5 \mathrm{~cm}$ long, very slender, stipules subulate [6].

\section{Botanical Classification}

\begin{tabular}{cc}
\hline Kingdom & Plantae- Plants \\
\hline Subkingdom & Tracheobionta-Vascular Plants \\
\hline Super division & Spermatophyta -Seed plants \\
\hline Division & Magnoliophyta -Flowering plants \\
\hline Class & Magnoliopsida-Dicotyledons \\
\hline Subclass & Dilleniidae- \\
\hline Order & Malvales- \\
\hline Family & Tiliaceae-Linden family \\
\hline Genus & Corchorus L. \\
\hline Species & Corchorusdepressus (L.) \\
\hline
\end{tabular}

Roots are diffusely branched. Flowers are yellowish, 1 $\mathrm{mm}$ long, occurring in 1-3 flowered axillary, orantiphyllous cymes. The growth of leaves and fruits is hindered in saline soil and stony soil [7]. The fruit is a capsule, 8-15 mm long, often curved upwards from the lower part of the branch, with a cylindrical beak, 4petaled, with or without compartments between the seeds [8]. Seeds are angular, smooth, oblong with sharp edges, minute, dark brown colored, and 1-2 $\mathrm{mm}$ in length with an obliquely truncate base. The stem is mostly adpressed to the ground, glabrous to sparsely pubescent [9].

\section{TRADITIONAL USES}

Various parts of the plant Corchorus depressus (L.) like roots, stems, leaves, seeds are used as remedies for many ailments. The plant contains various phytochemicals such as triterpenoids, alkaloids, phenolics, sterols, ionones, flavonoids, saponins, carbohydrates, and cardiac glycosides [10]. The plant has been traditionally used in pain, fever, and sexual dysfunction [11]. The entire plant is employed in folk treatments for a variety of ailments such as tumors, pain, pile fever, and emollient [12]. A decoction of the plant has found numerous ethnomedicinal uses, such as curing dysentery, dyspepsia, and liver disorders [13]. It is also utilized in the indigenous systems of drugs as a tonic and its mucilage is prescribed for treating gonorrhea [14].

\subsection{Leaves}

Plant leaves are used to prevent urinary stagnation and warmth stroke. The leaves of plants are more efficient emollient and an honest cooling agent. Its mucilage is employed for treating gonorrhea and in curing the skin eruptions [15]. The leaves are used to increase the viscosity of the semen [16]. The infusion of leaves is employed as demulcent, tonic, laxative, expectorant, antipyretic, diuretic and useful in chronic cystitis, dysuria [17], to extend sexual ability in males [18].

\subsection{Seeds}

Seed decoction is used as an energy supplement [19]. Seed water extract is employed in the treatment of nocturnal emissions and premature ejaculation [20]. Decoction of seed with goat milk and jaggery is used to treat acute diarrhea [21].

\subsection{Roots}

Roots are rubbed on stone and applied on forehead to relieve migraines [22].

\subsection{Stem bark}

Powdered stem gives a cooling effect during heat [23]. 


\subsection{Fruits}

Powdered dried fruit with milk is used to cure leucorrhoea in females [24].

\subsection{Whole plant}

The whole plant has been used for disorders such as hepatitis, liver inflammation, itching of urine, long-term bleeding during menstruation, and erectile dysfunction in men [25]. It is also used as an aphrodisiac, to treat swelling and damage to internal organs, urinary tract infections, and fever and to nourish the body [26-28]. It is found useful in gonorrhea, diabetes, betrayal disorders, improved sexual vitality, and jaundice [29-32]. The whole plant is used as a popular medicine in the disease of spermatids, treating muscle stiffness, treating dysentery, in tumors, indigestion [33-35].

\section{PHYTOCHEMICAL STUDIES}

Various secondary metabolites such as alkaloids, flavonoids, carbohydrates, cardiac glycosides, triterpenoids, phenolics, sterols, ionones are reported from the species $C$. depressus.

\subsection{Leaves}

The leaves of $C$. depressus contain various secondary metabolites, such as steroids, alkaloids, saponins, glycosides and phenolic compounds [36]. Leaves are reported to have flavonoids such as quercetin (1) and kaempferol (2) [37].

\subsection{Aerial Parts}

Samina evaluated the pharmacological constituents of the aerial parts $C$. depressus. The plant showed secondary metabolites like alkaloids, cardiac glycosides, and saponins (3) [38].

\subsection{Roots}

Patel et al., investigated the phytochemical composition of C. depressus (L.) roots. The hydroalcoholic extract of the roots contained phytochemicals such as saponins, flavonoids, steroids, carbohydrates and tannins. Also, methanolic extract of the plant showed flavonoids and steroids. The water extract showed phytochemicals such as glycosides, saponins, flavonoids, and tannin [39].

\subsection{Flowers}

Flavonoids like quercetin and kaempferol are isolated from the flowers of the plant.

\subsection{Seeds}

Shivhare et al., investigated the phytochemical activity of seeds of $C$. depressus and isolated depressogenin and glucopyranosides [40].

\subsection{Fruits}

Fruits and twigs of C. depressus (Linn) are crushed and eaten Nyman et al., reported the cardiotonic activity of fruits [41].

\subsection{Whole Plant}

Corchorus depressus contain various phytochemicals such as $\beta$-sitosterol (4), $\beta$-sitosterol- $\beta$-D -glucoside (5), apigenin (6), luteolin (7), and $\alpha$-amyrin derivatives. In 1991, Khan and coworkers isolated three $\alpha$-amyrin derivatives which includes cordepressic acid (8) ( $2 \alpha, 3 \beta, 20 \beta$-trihydroxy-urs-12-ene-24,28-di-oic acid), cordepressin (9) $(2 \alpha, 3 \beta, 20 \beta$-trihydroxy-urs-12-ene24,28 -di-oic acid $24 \quad \beta$-D-galactoside) and cordepressenic acid (10) (2 $\alpha, 3 \beta$ - dihydroxy-urs-12-20diene-24,28-dioic acid) [42]. In 1998, Viquar Uddin reported cycloartaneglucosides like depressoside $\mathbf{A}$ (11) (9,19-cyclolanosta- $22(\mathrm{R}), 25$ - epoxy - 3ß,16 $\beta, 24$ (S)-triol-3-O- $\beta$-D-glucopyranoside), depressoside B (12) (9,19-cyclolanosta-22(R),25-epoxy-24(S)acetoxy $3 \beta$, 16 $\beta$-diol-3-O- $\beta$-Dglucopyranoside) [43]. Viquar Uddin and coworkers in 2000 isolated two novel cycloartane-type glycosides such as depressoside C (13) ((22R) 16 $\beta, 22$-epoxy-3 $\beta, 26$-di-hydroxy-9,19cyclolanost-24E-ene-3,26-di-O- $\beta$-D-glucopyranoside) and depressoside D (14) $\{(22(\mathrm{R}), 24(\mathrm{~S})$-22,25-epoxy$3 \beta, 16 \beta, 24$-trihy-droxy-9,19-cyclolanostane 3,24-di-O$\beta$ - glucopyrano side $\}$ [44].

Zahid $\mathrm{M}$ and coworkers reported two new flavonol glycosides depressonol A (15) \{kaempferol-3-[B-Dglucopyranosyl-( $1 \rightarrow 4)-\beta$-D-galactopyranoside]7- $(\alpha-\mathrm{L}$ arabino- furanoside) and depressonol $\mathbf{B}(\mathbf{1 6})$ [kaempferol-3-[ $\beta$-D-glucopyranosyl- $(1 \rightarrow 6)-\beta$-D-

galactopyranoside] 7-( $\alpha$-L-arabinofuranoside). In 2002, two new mono desmosidiccycloartanetriterpene glycosides, namely depressosides E (17) \{(22R, 24S) -22,25-epoxy-9,19-cyclolanostane $3 \beta, 16 \beta, 24$ triol-3-[ $\alpha$-L-rhamnopyranosyl- $(1 \rightarrow 4)-\beta$-Dglucopyranoside $]\}$ and depressoside $F$ (18) $\{(22 \mathrm{R}, 24 \mathrm{~S})-22,25$ epoxy-9,19-cyclolanostane-3 $\beta, 16 \beta, 24$-triol-3[ $\alpha$-Dglucopyranosyl-( $1 \rightarrow 3)-\beta$-D-glucopyranoside] $\} \quad$ were reported [45]. 
<smiles>O=c1c(O)c(-c2ccc(O)c(O)c2)oc2cc(O)cc(O)c12</smiles>

(1) Quercetin

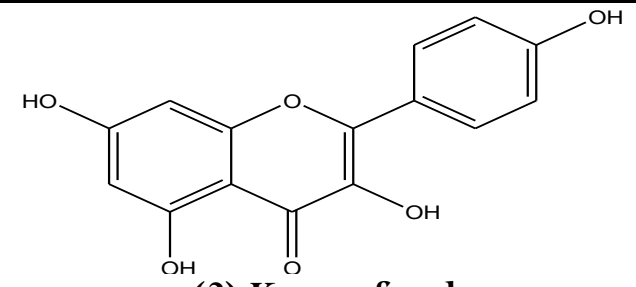

(2) Kaempferol

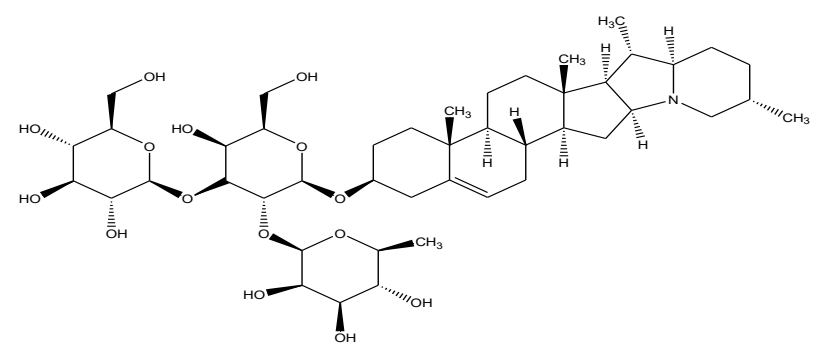

(3) Saponin<smiles>O=c1cc(-c2ccc(O)cc2)oc2cc(O)cc(O)c12</smiles>

(6) Apigenin

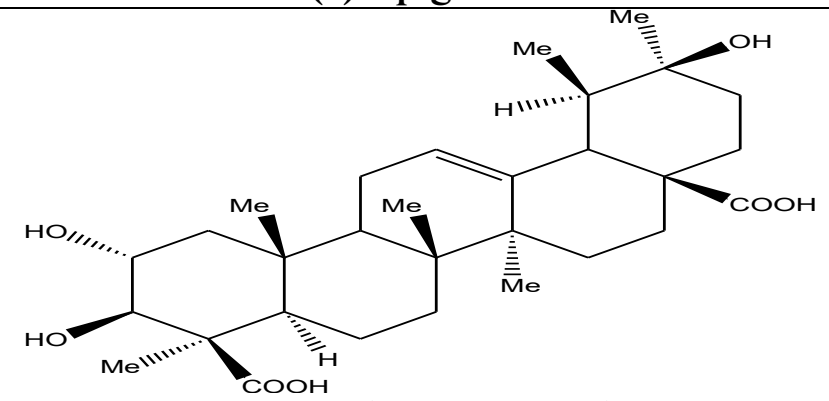

(8) Cordepressic Acid

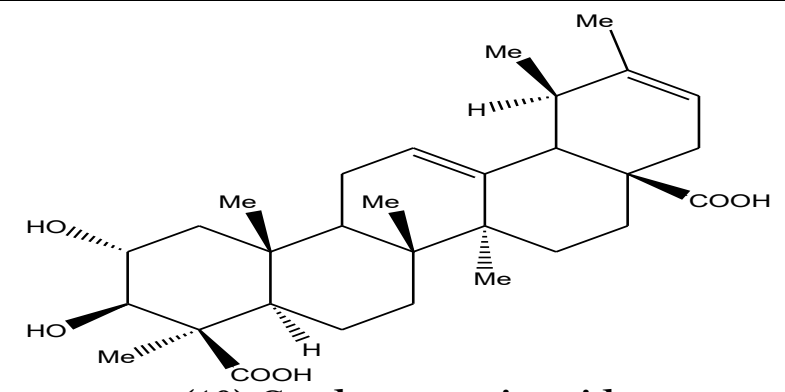

(10) Cordepressenic acid

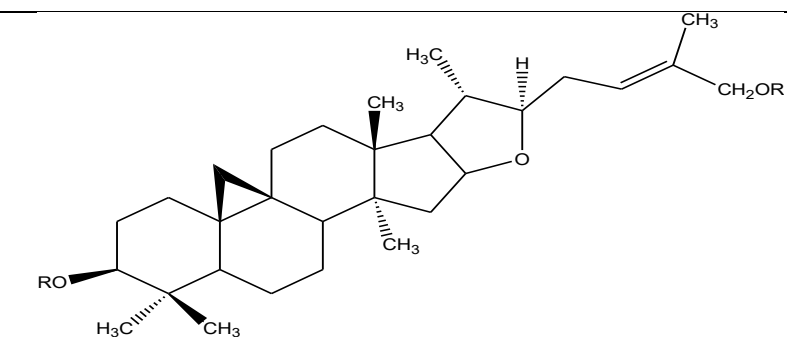

(13) Depressoside- $C(R=\beta-D$ glucopyranosyl $)$

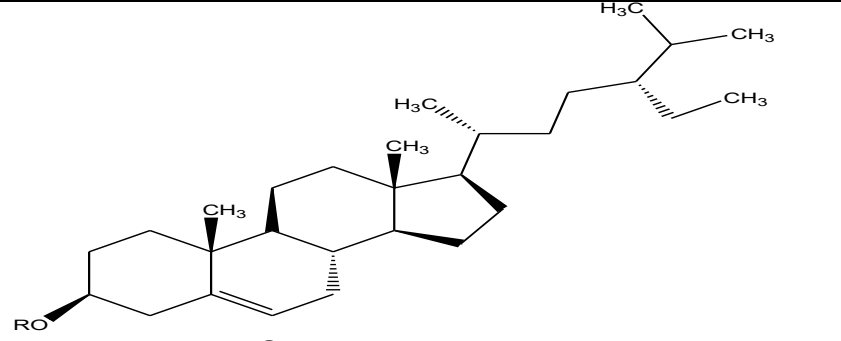

(4) $\boldsymbol{\beta}$-sitosterol $(\mathrm{R}=\mathrm{H})$

(5) $\beta$-sitosterol- $\beta$-D-glucoside $(R=$ Glucose $)$

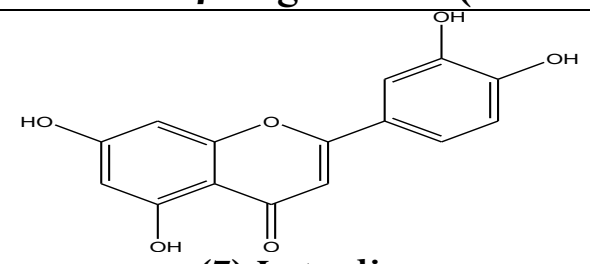

(7) Luteolin

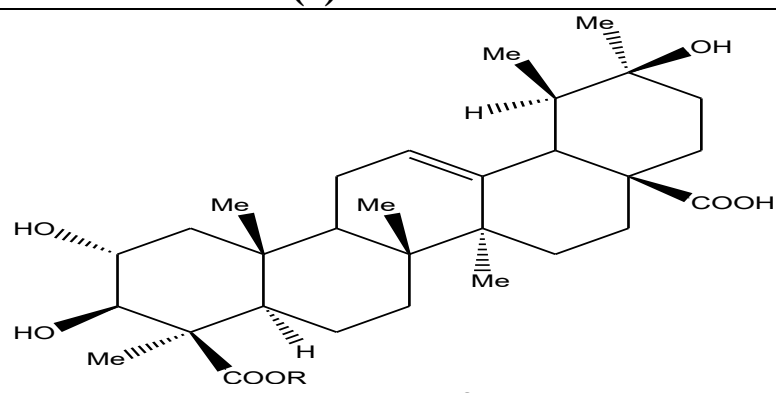

(9) Cordepressin $R=\beta-D$-Galactose

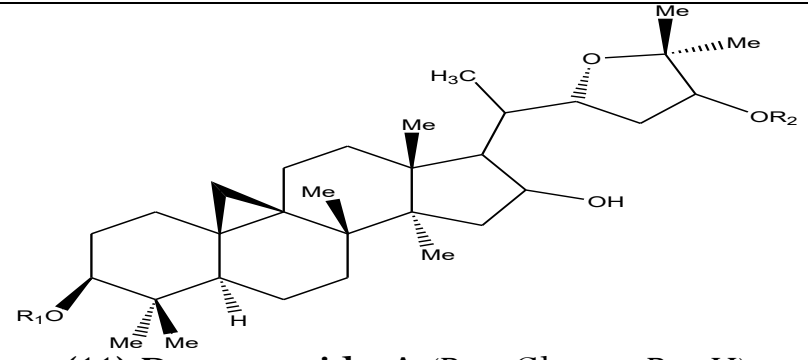

(11) Depressoside-A $\left(R_{1}=\right.$ Glucose,$\left.R_{2}=H\right)$

(12) Depressoside- $B\left(R_{1}=\right.$ Glucose, $\left.R_{2}=A c\right)$

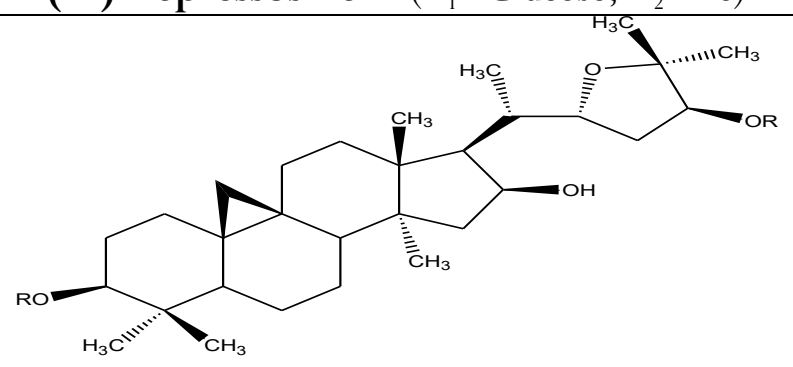

(14) Depressoside $D(R=\beta$-D-glucopyranosyl $)$ 


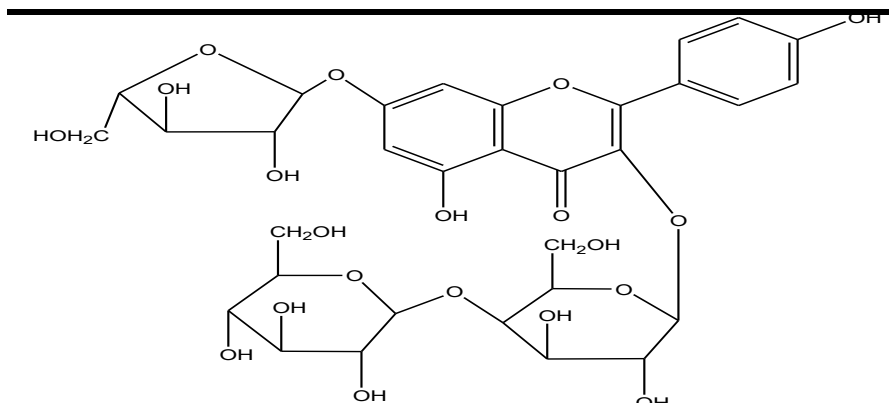

(15) Depressonol A
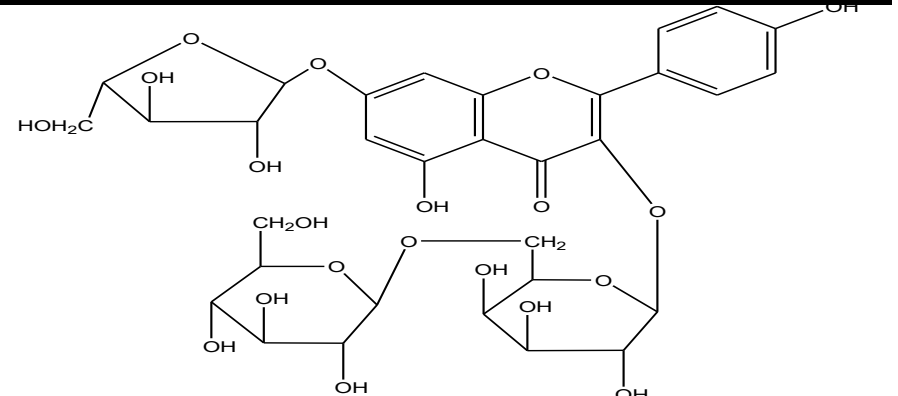

(16) Depressonol B

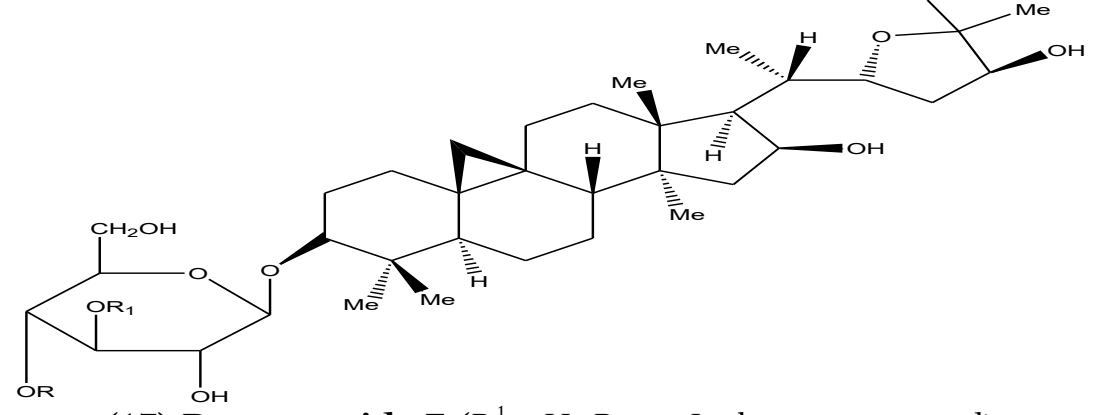

(17) Depressoside E $\left(R^{1}=H, R=\alpha\right.$-L-rhamnopyranosyl)

(18) Depressoside F $\left(R^{1}=\alpha\right.$-D-glucopyranosyl, $\left.R=H\right)$

\section{PHARMACOLOGICAL ACTIVITIES}

\subsection{Anti-oxidant Activity}

Jabeen et al., investigated for antioxidant activity of $C$. depressus (L.). Ethanol, methanol, acetone, ether and hexane extracts were analyzed for antioxidant activity using five assays such as DPPH, total flavonoids, total phenols, percent inhibition of the linoleic acid system, reducing potency analysis. Methanolic extract showed considerable antioxidant activity [46].

\subsection{Analgesic Activity}

Khuntia et al., investigated the analgesic activity of a $C$. depressus methanolic extract. It showed inhibition for the release of endogenous substances, which excites the pain nerve endings, incorporating the analgesic activity to the methanolic extract of the plant. The hot plate test method was used for the study of central analgesic effect [47].

\subsection{Antipyretic Activity}

Ikram et al., studied the antipyretic activity of whole plant $C$. depressus ( $L$.) in rabbits receiving yeast injections. Aspirin was selected as a standard antipyretic. At a dose of $150 \mathrm{mg} / \mathrm{kg}$ orally, hexane and chloroformsoluble extracts of the plant find potential antipyretic properties [48].

\subsection{Anti-inflammatory Activity}

Khuntia et al., investigated the anti-inflammatory activity of $C$. depressus methanolic extract (L.) It demonstrated potential anti-inflammatory activity in rat paw and cotton pellet induced granuloma models induced by carrageenan and egg-albumin. Methanolic extract contains a variety of secondary metabolites, such as flavonoids, which inhibit the release of inflammatory substances such as prostaglandins [49].

\subsection{Diuretic Activity}

M. A. Raza et al., [50] studied the diuretic properties of the plants. The decoction of aerial parts of the plant exhibited diuretic properties in the dosage of $500 \mathrm{~g} \mathrm{LA}$ and $200 \mathrm{~g} \mathrm{SA}$.

According to Kakrani and Saluja the whole plant can be used as a diuretic. Half a cup of the plant's aqueous decoction is consumed twice daily for 10-12 days [51].

\subsection{Wound Healing Activity}

Khan et al., studied the pharmacological properties of $C$. depressus. Leaves mucilage were reported to have wound healing property [52].

\subsection{Antifungal activity}

Methanol and Dichloromethane extracts of the plant were examined for antifungal activity by Samina et al. The plant was tested against A. niger, A. flavus, $F$. solani, A. fumigatus, and Mucor fungal strains. A dichloromethane extract of the plant's aerial parts inhibited A. niger growth by $80 \%$ or more. Furthermore, the methanol extract of the arial part and the dichloromethane extract of the plant's root inhibited 
A. flavus growth by more than $80 \%$. The methanol extract of the root part inhibited the growth of fungus $F$. solani by $55 \%$, and the dichloromethane extract of the plant inhibited growth by $64 \%$ [38].

\subsection{Antibacterial activity}

Kapoor et al., investigated the antibacterial activity of $C$. depressus against $S$. aureus, E. coli, and C. albicans pathogens. Various solvent extracts of leaves, such as ether and alcoholic extracts were studied. All of the extracts had strong antibacterial activity against these three bacteria types [53].

\subsection{Anti-diabetic activity}

Samina et al., assessed plant root extract's anti-diabetic activity. The dichloromethane extract of roots showed $79 \%$ inhibitory action against the $\alpha$-glucosidase enzyme with $\mathrm{IC}_{50} 62.8 \pm 1.5 \mu \mathrm{g} / \mathrm{ml}$ [54]. Also, Patel et al., reported that methanol and water extract of the plant showed potential inhibitory action against $\alpha$-amylase enzyme [39].

\subsection{Anti-cancer activity}

Kakrani studied the cytotoxic effect of arial parts of C.depressus. Methanol extract showed increased cytotoxicity in HepG2 and HLE human hepatocellular carcinoma cells at an inhibitory concentration of about $200 \mu \mathrm{g} \mathrm{IC}_{50}$. The highest cytotoxic effect has been recorded at $500 \mu \mathrm{g} / \mathrm{ml}[55]$.

\subsection{Hepatoprotective activity}

Anil Pareek investigated the hepatoprotective activity of the plant. The ethanolic extract prevented the $\mathrm{CCl}_{4}$ induced decay of antioxidant enzyme activities. This hepatoprotective effect was also evidenced by histological levels. C. depressus had a free radical scavenger that effectively protects the rat liver against oxidative damage induced by $\mathrm{CCl}_{4}$ and avoids the oxidation of detoxifying enzymes such as CAT and SOD [56].

\subsection{Aphrodisiac activity}

Ramandeep [57] looked into how different solvents, such as petroleum ether, chloroform, ethyl acetate, nbutanol, and aqueous fractions, affected the response. The methanolic extract of the whole plant of $C$. depressus had aphrodisiac action in rabbits. At a dosage of 25 $\mathrm{mg} / \mathrm{ml}$, chloroform extract was found to have a stronger aphrodisiac effect, causing 71.4 percent relaxation.

\section{CONCLUSION}

Since human evolution, plants and herbs have been used to treat and prevent disease all over the earth. About $25 \%$ of the drugs prescribed around the globe are of plant origin. Previous literature and current research of Corchorus depressus (L.) showed that leaves and roots consist of secondary metabolites, such as steroids, alkaloids, saponins, glycosides, and phenolic compounds, which would be a wonderful in producing recent medicine to cure illness. This plant grows chiefly in wild areas.

An exhaustive literature search of phytochemicals in Corchorus depressus(L.) indicates the presence of several secondary metabolites such as $\beta$-sitosterol, $\beta$-sitosterol$\beta$-D-glucoside, apigenin, luteolin, and $\alpha$-amyrin derivatives. Also, cyclartane type glycosides and some $\alpha$-amyrin derivatives have been isolated from various parts of the plant. These phytochemicals incorporated important pharmacological properties such as antimalarial, antipyretics, aphrodisiac, diuretics, antifungal, wound-healing activity, and anti-diabetic properties.

This review reveals an important medicinal and indigenous significance of the plant and still a broad scope is left to investigate more of its properties in the field of phytochemistry. As a result, we hope that phytochemical research and pharmacological properties will aid and attract researchers in the discovery of new drugs as well as the isolation, identification, and characterization of the structures of various active compounds responsible for these activities. To rationally use the plant as an effective herbal medicine, the pharmaceutical industry must take innovative measures and gather the necessary evidence.

\section{ACKNOWLEDGEMENT}

The authors are thankful to Principal, P. S. G. V. P. Mandal's S. I. Patil Arts, G. B. Patel Science and S.T.K.V.S Commerce College, Shahada, DistNandurbar (MS) for providing necessary facilities. This work was also supported by Principal, Sandip Institute of Technology and Research Centre, Nashik for providing the research facilities.

\section{Conflict of interest}

The authors declare no conflict of interest.

\section{REFERENCES}

1. Tilburt JC, Kaptchuk Ted J. Bulletin of WHO, 2008; 86:594-599. 
2. WHO, General Guidelines for Methodologies on Research and Evaluation of Traditional Medicine, World Health Organization, 2000; 1:1-5.

3. Subhose V, Srinivas P, Narayana A. Bulletin of the Indian Institute of History of medicine, 2005; 35(2):83-92.

4. Singh LK. Indian Cultural Heritage Perspective for Tourism; Gyan Publishing House; 2008.

5. Mukherjee PK, Harwansh RK, Bahadur S, Kar A, Ahmed SK, Pulok KM et al. Journal of Ethnopharmacology, 2017; 197:10-24.

6. Kirtikar KR, Basu BD. Indian medicinal plants; L M Basu Publication, 1993; 397-403.

7. Bokhari TH et al. Bulgarian Chemical communication, 2014; 46(4):788-794.

8. Mathur M, Sundarmoorthy S. Tropical Ecology, 2008; 49(1):69-71.

9. Nael M, Fawzi. Middle East Journal of Agriculture, 2018; 7(1):1-11.

10. Khan MSY, Bano S, Javed K, Asad Mueed M. Journal of Sci. \&Industrial Research, 2006; 65:283-298.

11. Jain A, Katewa SS, Chaudhary BL, Galay P. Indian J. Ethnopharmacology, 2004; 90:171-177.

12. Sinha MK, Kar CS, Ramasubramanian T, Kundu A, Mahapatra BS, Erratum to Chapter 2: Corchorus. In: Kole C. (eds) Wild Crop Relatives: Genomic and Breeding Resources. Springer, Berlin;2011.

13. Kapoor BBS, Arora V. International Journal of Ethnobiology and Ethnomedicine, 2014; 1(1):1-6.

14. Zareen A, Khan Z, Aajaib M. Biologia (Pakistan), 2013; 59(1):139-146.

15. Saleem SM, Yasin AM, Sarwar G. Pakistan Journal of Biological Sciences, 2001;4(1): 112-116.

16. Wahid A, Siddiqui H H.A Survey of Drugs; $2^{\text {nd }}$ Edn. IHMMR, Delhi, 1961.

17. Satyawati G. V, Raina MK, Sharma M. Medicinal Plants of India, ICMR, New Delhi, 1976; (1):278-281.

18. Bhatt DC, Patel AM, Parekh PP, Parmer RP. J. Econ. Taxon. Bot, 2003; 27:943-946.

19. Khan TM, Habib U, Saleem A, Khan MQ, Khan SS, Shah MA, Ilyas MK. International Research Journal of Pharmacy, 2012; 3(12):74-78.

20. Qureshi R, Raza BG. Fitoterapia, 2008; 79(6):468-473.

21. Ph.D. thesis, Manju Chaudhary, University of KOTA. Ethnobotanical studies of Beer Jhunjhunu Conservation Reserve of Jhunjhunu District of Rajasthan and Screening of selected plant species for their antimicrobial activity.

22. Upadhyay B, Parveen AK, Dharkar AK. Journal of Ethnopharmacology, 2010; 129:64-86.

23. Suresh Kumar, F. Parveen, Pratap Narain. Medicinal Plants in Indian Arid Zone, 9-13.

24. Upadhyay BP, Dhaker AK, Ashwani Kumar, Journal of Ethnopharmacology, 2010; 129: 64-86.

25. Tripathi YC, Sharma HK, Arya R. J. Med. Aroma Plant Sci.2000; 22(4A):497-498.
26. Ahmad S, Warris HM, Alam K, Anjum S, Mukhtar M.. Int. J. Sci. Res, 2014; 3(6):1782-1788.

27. Sharma MP, Ahmad J, Hussain A, Khan S. Indian J Pharmacog. 1992; 30:129-134.

28. Singh AK, Raghubanshi AS, Singh JS. J. Ethnopharmacol, 2002; 81:31-41.

29. Chopra RN, Nayar SL, Chopra IC. Glossary of Indian Med Plants, CSIR, 1956.

30. Kirtikar KR, Basu BD. Indian medicinal plants. Delhi: Jayyed Press, 1975; p.1581.

31. Kumar S, Praveen F, Mertia RS. Journal of Economic and Taxonomic Botany, 2003; 27:160-169.

32. Shekhawat, GS. Ethnobotanical Survey of Desert Area of Rajasthan.Ph.D.Thesis, University of Jodhpur, 1986.

33. Kapoor BBS, Versha Arora. Int.Jou.of Ethno. and Ethnomedicine, 2014; 1(1):1-6.

34. Duke JA, Wain KK. Medicinal plants of the world. Computer Index, 1981.

35. Patil PS, Dushing YA, Patil DA. Ancient Science of Life, 2007; 27(1):43-49.

36. Kataria S, Rao SK, Bhandari Anil, Kaur D. Ind. Journ. of Traditional Knowledge, 2013; 12(3):489-497.

37. Harsh. ML, Nag, TN. Geobios, 1988; 15(32): 5.

38. Samina A, Chaudhary BA, Ashfaq Ahmad, Khurram A. Acta Poloniae Pharmaceutica -Drug Research, 2015; 72(2):329-334.

39. Bhatt PR, Pandya KB, Patel UB, Modi CM, Patel HB, Javia BB. Annals of Phytomedicine, 2019; 8(2):75-84.

40. Shivhare Y, Singh P, Singh S, Bharti PK, Tiwari R. Resear. J. of Pharm. \&Tech, 2011; 4(2):182-183.

41. Nyman U, Joshi P, Madsen LB, Pedersen TB, Pinstrup M, Rajasekharan S, et al. J Ethnopharmacol, 1998; 60:247-263.

42. Khan MSY, Javed K, Khan MH, Shamsi MA, Siddiqui AA. Phytochemistry, 1991; 30:1989-1992.

43. Ahmad VU, Ali Akbar, Ali ZB, Fehmida T, Zafar FN A. Phytochemistry, 1998; 49(3):829-834.

44. ViqarUddin AA, Ali Zulfiqar, Zafar FN, Zahid M. Chem. Pharm. Bull, 2000; 48(11):1597-1601.

45. Zahid. M, Ali A, Ishurd O, Ahmed A, Ali Z, Ahmad V, Pan Y. Helv Chim Acta, 2002; 85:689-697.

46. Zahra J, Bukhari IH, Qurat-Ul-Ain, Solat P, Aslam N, Shagufta. Intern.Jour.of current pharm. Research, 2014; 6(1):17-21.

47. Khuntia TK, Nanda UN, Senapati AK. World Jour. of Pharm. \& pharmaceutical sciences, 2017; 6(1):619-636.

48. Ikram M, Khattak SG, Gilani SN. Journal of Ethnopharmacology, 1987; 19:185-192.

49. Khuntia TK, Nanda UN, Senapati AK. MIT International Journal of Pharmaceutical Sciences, 2017; 3(1):16-20.

50. Raza MA, Younas M, Buerkert A, Eva Schlecht. Journal of Ethnopharmacology, 2014; 151:333-342.

51. Kakrani HN, Saluja AK. Ind. J. Nat. Rem, 2001; 1:121124. 
52. Khan RU, Mehmood S, Khan SU, Subhan M. Journal of Medicinal Plant studies, 2013; 1(4):49-78.

53. Kapoor BBS, Mishra R, Acharya S, Lakhera S, Purohit V. UJEAS, 2013; 01(01):38-40.

54. Afzal S, Chaudhary BA, et al. Pharmacognosy Magazine, 2017; 13(52):647-651.
55. Kakrani PH, Kakrani HN, Raval M. Asian Journal of Pharmaceutical and clinical research, 2018; 11(12):187189.

56. Pareek A, Yadav SK, Desai P, Godvarthiv A, Nagori BP.Pharmac Communications, 2013; 3(3):22-28.

57. Singh R, Ali Ashraf, Gupta G, Alok S, Jeyabalan G. Journal of Acute Disease, 2013; 179-188. 